How to Cite

Zambrano, T. Y. M., Mero, T. B. B., Mendoz, V. D. P., \& Giler, R. D. G. (2019). Transesterification of vegetable oil of higuerilla (ricinuscommunis 1) for biofuel generation and cost determination. International Journal of Life Sciences \& Earth Sciences, 3(1), 1-7. https://doi.org/10.31295/ijle.v3n1.96

\title{
Transesterification of Vegetable Oil of Higuerilla (Ricinuscommunis L) for Biofuel Generation and Cost Determination
}

\author{
Telly Yarita Macías Zambrano \\ Instituto Superior Tecnológico Paulo Emilio Macías, Portoviejo, Ecuador \\ Corresponding Author Email: itspem.tmacias@gmail.com \\ Tanya Beatriz Bravo Mero \\ Universidad Técnica de Manabí, Portoviejo, Ecuador \\ Email:tanyi16@hotmail.com \\ Verónica Dolores Palma Mendoz \\ Instituto Superior Tecnológico Paulo Emilio Macías, Portoviejo, Ecuador \\ Email: itspem.vpalma@gmail.com \\ Rosa Delfina Giler Giler \\ Instituto Superior Tecnológico Paulo Emilio Macías, Portoviejo, Ecuador \\ Email: itspem.dgiler@gmail.com
}

\begin{abstract}
The limited use of natural resources that are possessed, which implies endemic flora (shrubs, herbs, etc.) and production waste ( leaf litter, various plant fibers, cattle manure, poultry, etc.), which are stacked for later burning and consequently causing pollution to the environment, are some of the problems that are generated at the farm level. The objective of the research was to generate biofuel derived from the mixture of methanol, sodium hydroxide and fig oil in the Mis 2 Principitos del Comuna El Limón farm, Portoviejo canton. Within the methodology to produce biodiesel or biofuel through the transesterification process, castor oil obtained from the fig seed, methanol (methyl alcohol) and potassium hydroxide $(\mathrm{KOH})$ (acid or catalyst) were used. By means of the transesterification in which $0.001 \mathrm{~m} 3$ of castor oil, $0.0001 \mathrm{~m} 3$ of methanol and $0.01 \mathrm{Kg}$ of potassium hydroxide were used under conditions of an approximate temperature of $60^{\circ} \mathrm{C}$ and $40 \mathrm{rpm}$ of agitation in the stirrer plate, it resulted in $0.001 \mathrm{~m} 3$ of biodiesel. Biodiesel can be generated from fig or castor oil, taking advantage of a biomass energy source, which can be used in pump engines for irrigation in farms.
\end{abstract}

Keywords--- vegetable oil, methanol, transesterification, cost.

\section{Introduction}

Renewable energy can be defined as "energy flows that are replaced at the same rate at which they are used" (Alexander \& Boyle, 2014). The energy obtained from the continuous energy flows that exist in the natural environment is what is known as renewable energy (Castro, 2011). Renewable energies have been used for several decades, especially in rural areas where the lack of electric power has been felt for its various uses, which has meant that to meet this need the farmer must use fuels such as diesel to light your home, to start engines and irrigation pumps that are used daily in agriculture.

The main primary source of almost all existing energies on earth is solar energy. The potential of renewable sources is gigantic since the energy existing in them can meet the current global energy demand several times (Kammen, 2014; Singh, 2016). According to information obtained from the (WEC, 2010) "The total amount of radiation that the sun radiates on the earth in a year is 7500 times greater than the annual global energy

ISSN 2632-9425

Received May 05, 2019/Accepted August 30, 2019/Published September 09, 2019 
consumption." Climate change, the peak (or zenith) oil and energy security are the global trends that begin to set the pace of the energy transition required to meet the growing demand for global energy while abandoning that which has been the main energy source to the present: fossil fuels. Faced with this chal

lenge, renewable energy source technologies are receiving strong incentives and development stimuli globally. This has allowed several of them to become competitive in the face of traditional energy generation alternatives and begin to have a commercial deployment and use. for example, in the province of Manabí there are considerable solar radiation conditions to make investments that do not contaminate (Rodríguez, 2018; Ermayanti et al., 2016).

In Ecuador, the last 25 years of investment in renewable energy sources have allowed cost reductions in values of $40 \%$ in biomass-related technologies, $70 \%$ in geothermal energy and $90 \%$ in wind, photovoltaic and solar thermal energy (Paredes \& Ramírez, 2017). It is considered that for these technologies to have the potential to be used in Ecuador, they are in the deployment and commercialization phase. Renewable energies are a practical and environmentally friendly alternative, especially in the current times when the planet is going through severe climatic changes that particularly affect agricultural fields and ecosystems in general. In this way, the generation of biofuel or biodiesel from biological material, such as vegetable oils, wood residues, manures, etc. has been promoted. Biodiesel generated from vegetable oils releases less $\mathrm{CO}$ when burned by an engine and does not generate sulfur trioxides (SO3), thus avoiding acid rain (Cornejo \& Estrada, 2012; Vivas et al., 2017).

One of the plants used for the generation of biodiesel is the higuerilla (Ricinos communis L.) characterized by its high tolerance to drought, this condition allows the crop to be economically viable in semi-arid environments where there are water shortages. The industrialization of the fig tree originates as a by-product the pasta or also called cake, it is rich in proteins and can be used in the restoration of degraded soils, it also contains products that can be used for the control of nematodes in the soil, because It contains the protein called highly toxic ricin, it is concentrated in the endosperm of the seed, remains in the cake after oil extraction, it is worth mentioning that this protein is soluble in water.

The current conception of a productive and sustainable farm tends to the use of alternative energy sources that contribute to the integrality of the farm, taking better advantage of the organic waste generated by agricultural production for the benefit of the farm as such. Traditional agricultural farms dedicated to the production of varied crops, the breeding of cattle and pigs, and poultry are found daily with a certain volume of organic waste such as leaf litter, stems, fallen, dried and moist fruits, cattle manure, pig, poultry, etc. that constitute an obstacle for the farmer in terms of time and money, since the way in which the waste has been handled inside the farm is with stacking and burning.

To take advantage of all the waste generated within the farm, the use of renewable energy sources is required, such as the generation of biogas from all the biomass collected, the installation of solar panels to take advantage of solar radiation and obtaining Biofuel from the fig tree that grows natively in much of the farm. From an environmental point of view, the use of renewable energy is an alternative to the cost of electric energy, to petroleum-derived fuel, to liquefied petroleum gas for cooking food and heating.

One of the most frequent limitations that occurs in the Finca Mis dos principitos is the scarce use of natural resources that are possessed, which implies endemic flora (shrubs, herbs, etc.) and production waste (litter, various vegetable fibers, cattle manure, poultry, etc.), which are stacked for later burning, resulting in pollution to the environment. The participation of families in the daily activities of the farm is essential to maximize the productivity of the farm and minimize production costs, since the payment in day laborers comes to represent a large percentage of the income that can be obtained from the sale of agricultural products, limiting the tendency to tend towards a more sustainable farm from a social, economic and environmental point of view; also tending to affect the welfare and productive capacity of the farmland.

The objective of the present investigation was to generate biofuel derived from the mixture of methanol, sodium hydroxide and fig oil in the Mis 2 Principitos de la Comón el Limón farm, Portoviejo canton, also determining production costs.

\section{Materials and Methods}

To produce the biodiesel or biofuel through the transesterification process, castor oil obtained from the fig seed, methanol (methyl alcohol) and potassium hydroxide $(\mathrm{KOH})$ (acid or catalyst) were used. 
Table 1

Materials used to obtain biofuel

\begin{tabular}{ll}
\hline Material & Units \\
\hline Castor oil & $0.001 \mathrm{~m}^{3}$ \\
Methanol & $0.0001 \mathrm{~m}^{3}$ \\
Potassium hydroxide & $0.01 \mathrm{Kg}$ \\
\hline
\end{tabular}

Source: (Macías, 2018)

\section{Results and Discussions}

\section{Transesterification process}

The process is the chemical reaction of an alcohol, an oil and acid or catalyst, which means that the glycerol contained in castor oil is replaced by methanol in the presence of potassium hydroxide (Cornejo \& Estrada, 2012).

For the transesterification, $0.001 \mathrm{~m} 3$ of castor oil, $0.0001 \mathrm{~m} 3$ of methanol (10\% of the total volume of castor oil) and $0.01 \mathrm{Kg}$ of potassium hydroxide ( $1 \%$ of the total volume of castor oil were used).

The methanol is mixed with the potassium hydroxide in a stirring plate using a beaker containing a magnetic stirrer. The methanol is placed in the glass and the catalyst is added little by little, controlling the temperature that should not exceed $80^{\circ} \mathrm{C}$, for approximately 8 minutes, during which time the potassium hydroxide has been completely diluted. The castor oil volume is immediately added at room temperature, setting the stirrer plate at 40 rpm to obtain a temperature of $60^{\circ} \mathrm{C}$.

It is controlled that the temperature does not rise, until the transesterification process is finished, observing that the color of the mixture is kept in a strong yellow hue and its consistency is dense. When these indicators were reached, the mixture is removed from the stirrer and the mixture is allowed to stand, which by decantation proceeds to separate the glycerin from the biofuel.

The biodiesel or biofuel B-100 extracted in the transesterification process was subjected to practice in a 7457 Watt engine, using combinations of diesel and biodiesel in percentages of 5\% and 20\% diesel to obtain biofuel B5 and B 20. Subsection should be written without a bold type. The result and analysis are presented in the present form. Please avoid too many paragraphs in this section.

\section{Development of biodiesel type B5}

To produce $0.001 \mathrm{~m} 3$ of biodiesel of type B5, 95\% of conventional diesel and 5\% of biofuel are combined. Taken $0.000050 \mathrm{~m} 3$ of castor oil and $0.000950 \mathrm{~m} 3$ of diesel are mixed and obtained $0.001 \mathrm{~m} 3$ biofuel type B-5.

\section{Watt engine test}

A sample of $0.0001 \mathrm{~m} 3$ of biofuel type B-5 was taken to start a 7457 Watt engine, controlling the temperature and the time the biodiesel was consumed. The consumption time of the biofuel was 0.07 hours, reaching a temperature of $136^{\circ} \mathrm{C}$.

Calculation of the volume of B5 to power a pump of 7457 Watts during 6 hours of irrigation

To know the volume in $\mathrm{m} 3$ of biofuel of type B5 that are required to start a diesel pump of power 7457 Watts, used in the integral farm, the following relation was made: use equation (1)

$$
\begin{aligned}
& \frac{6 \text { hours }}{0.07 \text { hours }}=85.71 \\
& 85.71 * 0.001 \mathrm{~m}^{3}=0.08571 \mathrm{~m}^{3}
\end{aligned}
$$

The calculation made indicates that a volume of $0.08571 \mathrm{~m}^{3}$ of biofuel is needed of the type B-5 to be able to water for 6 hours with a pump of 7457 Watts of power. Use equation (2).

$$
\begin{aligned}
& \frac{6 \text { hours }}{0.123 \text { hours }}=48.78 \\
& 48.78 * 0.001 \mathrm{~m}^{3}=0.04878 \mathrm{~m}^{3}
\end{aligned}
$$


The calculation made indicates that a volume of $0.04878 \mathrm{~m}^{3}$ of biofuel of the type is needed B-20 to be able to water for 6 hours with a pump of 7457 Watts of power.

Test of the B-100 in a 7457 Watt engine

A sample of $0.0001 \mathrm{~m} 3$ of biofuel of the B-100 type was taken to start a 7457 Watt engine, controlling the temperature and the time the fuel was consumed biodiesel the consumption time of the biofuel was 0.089 hours, reaching a temperature of $167^{\circ} \mathrm{C}$.

Calculation of the volume of B-100 to power a pump of 7457 Watts during 6 hours of irrigation

To know the volume in $\mathrm{m} 3$ of biofuel of the type B-100 that are required to start a diesel pump of power 7457 Watts, used in the integral farm, the following relation was made: Use equation (3).

$$
\begin{aligned}
& \frac{6 \text { hours }}{0.089 \text { hours }}=67.42 \\
& 67.42 * 0.001 \mathrm{~m}^{3}=0.06742 \mathrm{~m}^{3}
\end{aligned}
$$

The calculation made indicates that a volume of $0.06742 \mathrm{~m}^{3}$ of biofuel of the type is needed B-100 to be able to water for 6 hours with a pump of 7457 Watts of power.

Calculation of unit prices for obtaining biofuel

Table 2

Calculation of unit prices for obtaining biodiesel

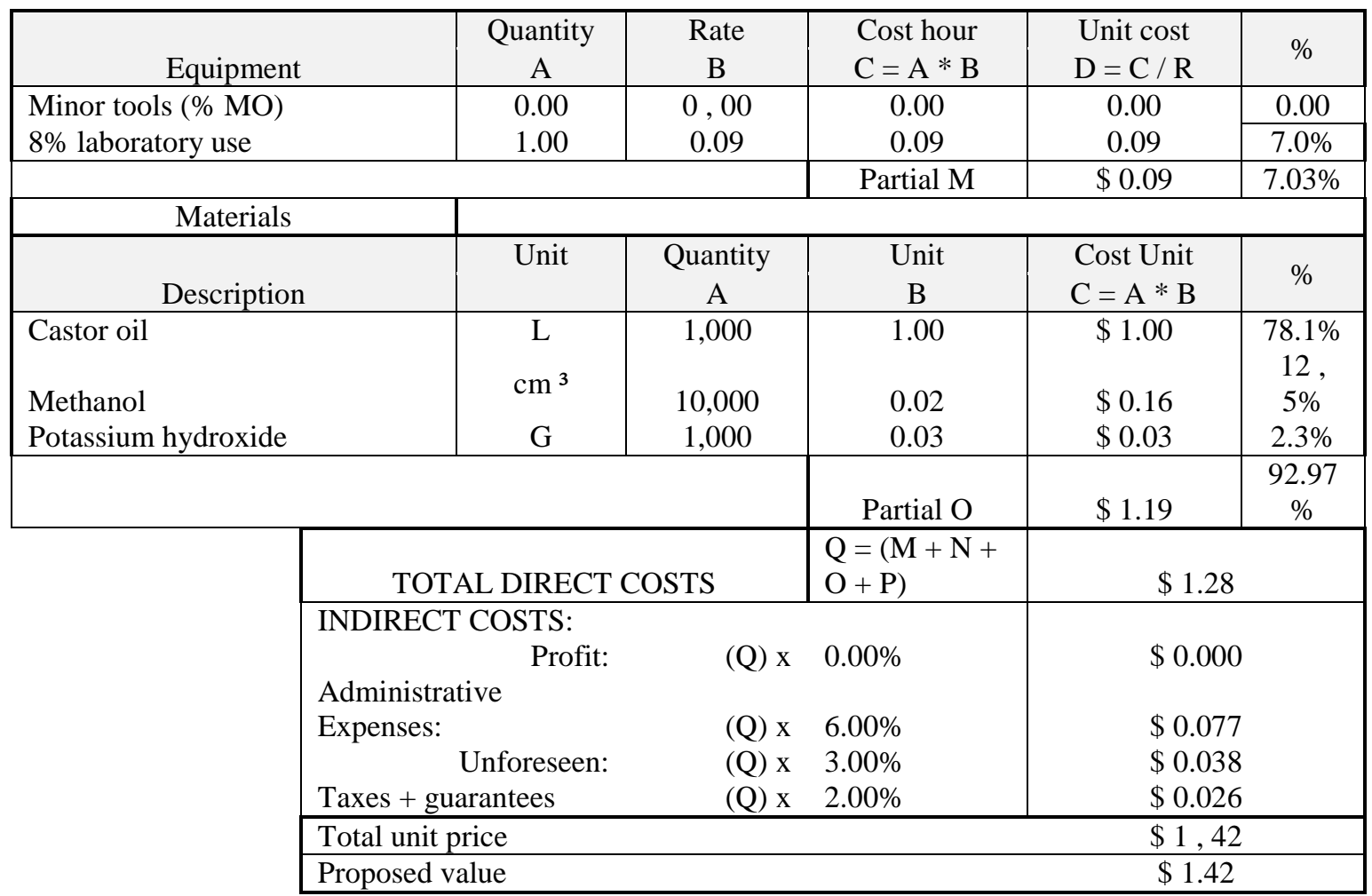

Through the transesterification process in which $0.001 \mathrm{~m} 3$ of castor oil, $0.0001 \mathrm{~m} 3$ of methanol and $0.01 \mathrm{Kg}$ of potassium hydroxide were used under temperature conditions Approximately $60{ }^{\circ} \mathrm{C}$ and $40 \mathrm{rpm}$ of agitation on the agitator plate, $0.001 \mathrm{~m}$ were obtained 3 of biodiesel. 
Table 2. Shows the elements used in the transesterification process

Table 2

Elements for transesterification

\begin{tabular}{llllll}
\hline $\begin{array}{l}\text { Castor oil } \\
\left(\mathrm{m}^{3}\right)\end{array}$ & $\begin{array}{l}\text { Methanol } \\
\left(\mathrm{m}^{3}\right)\end{array}$ & $\begin{array}{l}\mathrm{KOH} \\
(\mathrm{Kg})\end{array}$ & $\begin{array}{l}\mathrm{T} \\
\left({ }^{\circ} \mathrm{C}\right)\end{array}$ & $\begin{array}{l}\text { Agitation } \\
(\mathrm{rpm})\end{array}$ & $\begin{array}{l}\text { Biodiesel } \\
\text { obtained } \\
\left(\mathrm{m}^{3}\right)\end{array}$ \\
\hline 0.001 & 0.0001 & 0.01 & 60 & 40 & 0.001 \\
\hline
\end{tabular}

For generation $0.001 \mathrm{~m} 3$ of biofuel from castor oil, three types of biodiesel were determined. Table 3 shows the volume of vegetable oil and diesel used to produce 3 types of biodiesel.

Table 3

Biodiesel

\begin{tabular}{llllll}
\hline $\begin{array}{l}\text { Type of } \\
\text { biodiesel }\end{array}$ & $\begin{array}{l}\text { oil } \\
\text { generation castor } \\
\left(\mathrm{m}^{3}\right)\end{array}$ & $(\%)$ & $\begin{array}{l}\text { Diesel } \\
\left(\mathrm{m}^{3}\right)\end{array}$ & $(\%)$ & $\begin{array}{l}\text { Biodiesel } \\
\text { obtained } \\
\left(\mathrm{m}^{3}\right)\end{array}$ \\
\hline B-5 & 0.00005 & 5 & 0.00095 & 95 & 0.001 \\
B-20 & 0.0002 & 2 & 0.00080 & 80 & 0.001 \\
B-100 & 0.001 & 100 & - & 0 & 0.001 \\
\hline
\end{tabular}

The types of biodiesel obtained were tested in a 7457 Watts power pump for irrigation. Figure 1 shows the melting temperature by type of biodiesel

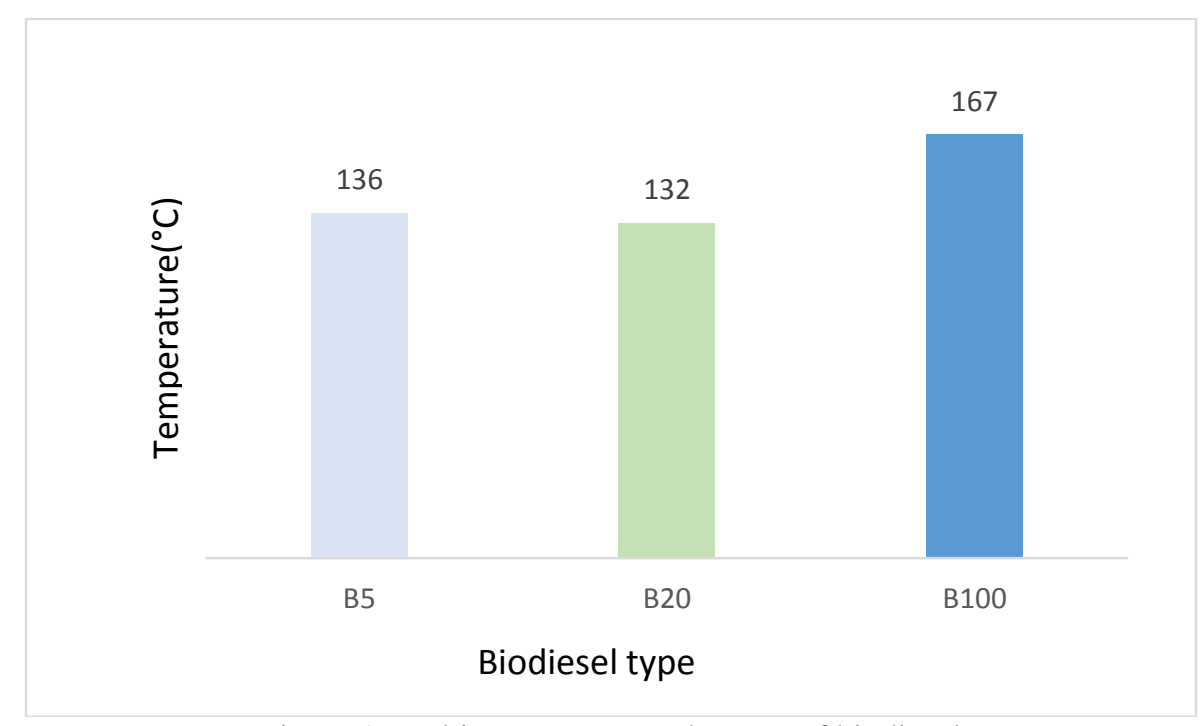

Figure 1. Melting temperature by type of biodiesel

The consumption time was experienced with the same sample volume and type of biodiesel, obtaining the results shown in Figure 2. 


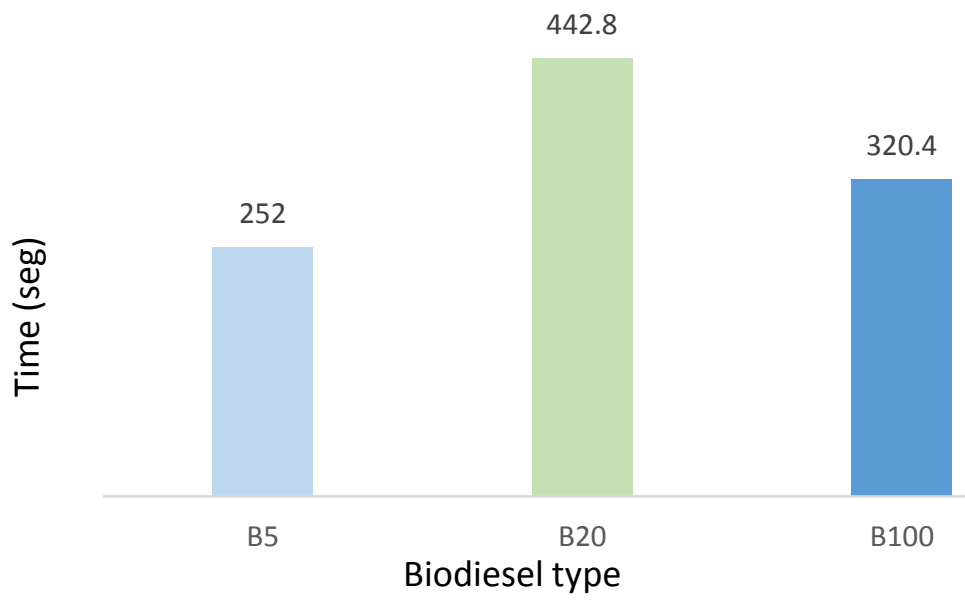

Figure 2. Time of consumption by type of bodies

Table 4 details the volume per type of biodiesel required for irrigation in a given number of hours with a pump motor for irrigation of 7457 Watts of power.

Table 4

Biodiesel requirement for hours of irrigation in a 7457 Watt pump engine

\begin{tabular}{lllllllll}
\hline $\begin{array}{l}\text { Type of } \\
\text { biodiesel }\end{array}$ & $\begin{array}{l}\text { Volume } \\
\left(\mathrm{m}^{3}\right)\end{array}$ & $\begin{array}{l}\text { Time } \\
\text { (hours) }\end{array}$ & $\begin{array}{l}\text { Volume } \\
\left(\mathrm{m}^{3}\right)\end{array}$ & $\begin{array}{l}\text { Time } \\
\text { (hours) }\end{array}$ & $\begin{array}{l}\text { Volume } \\
\left(\mathrm{m}^{3}\right)\end{array}$ & $\begin{array}{l}\text { Time } \\
(\text { hours })\end{array}$ & $\begin{array}{l}\text { Volume } \\
\left(\mathrm{m}^{3}\right)\end{array}$ & $\begin{array}{l}\text { Time } \\
\text { (hours) }\end{array}$ \\
\hline B-5 & 0.02857 & 2 & 0.05714 & 4 & 0.08571 & 6 & 0.11428 & 8 \\
B-20 & 0.01626 & 2 & 0.03252 & 4 & 0.04878 & 6 & 0.06504 & 8 \\
B-100 & 0.02247 & 2 & 0.04494 & 4 & 0.06742 & 6 & 0.08988 & 8 \\
\hline
\end{tabular}

To install a biofuel system derived from the mixture of methanol, potassium hydroxide and fig oil on the Mis 2 Principitos farm, which will be used as a biofuel of type B5 (5\% biofuel and 95\% diesel) to be used in the commissioning of two $5 \mathrm{HP}$ diesel pumps for the irrigation of 4 ha of banana and coconut palm cultivation, 60 liters of B5 per month is required and of an investment of USD \$1.62.

The total budget for obtaining biofuel from transesterification with the indicated elements, which is $\$ 1.62$ to produce $0.001 \mathrm{~m}^{3}$ of biodiesel or B-100.

To produce $0.001 \mathrm{~m}^{3}$ of $\mathrm{B} 5$ and $\mathrm{B} 20$, a simple rule of three is applied, to the value obtained the price of the percentage to be used of diesel is added according to the type of biofuel and the following costs are obtained as shown in Table 5.

Table 5

Price of types of biodiesel per $0.001 \mathrm{~m}^{3}$

\begin{tabular}{|c|c|c|c|c|c|c|c|}
\hline & \multicolumn{7}{|c|}{ Price $(\$)$} \\
\hline $\begin{array}{l}\text { Type of } \\
\text { biodiesel }\end{array}$ & $0.0005 \mathrm{~m}^{3}$ & $0.0002 \mathrm{~m}^{3}$ & $0.001 \mathrm{~m}^{3}$ & $0.00095 \mathrm{~m}^{3}$ & $0.0008 \mathrm{~m}^{3}$ & $0.001 \mathrm{~m}^{3}$ & $\begin{array}{l}\text { total per type } \\
\text { of biodiesel }\end{array}$ \\
\hline B5 & $\$ 0.08$ & & & $\$ 0.025$ & & & 0.11 \\
\hline B20 & & $\$ 0.32$ & & & 0.021 & & 0.34 \\
\hline B100 & & & 1.62 & & & & 1.62 \\
\hline B0 (diesel) & & & & & & 0.26 & 0.26 \\
\hline
\end{tabular}


According to the Manual of the (OLADE, 2014) on the generation of renewable energy sources, in the southern countries of America work is being done to obtain biofuel from soybeans and Bolivia is experimenting with obtaining ethanol from sugarcane. Although the emphasis is placed on food security, it is clear that the main purpose of the crop is focused on another market, biofuel production, putting the population's food security at risk.

In the present case, biofuel has been generated from the fig tree with a mixture of methanol and potassium hydroxide in types B-5, B-20 and B-100. The results obtained in the aforementioned mixture to obtain biofuel, prioritize castor oil or higuerilla because it is a plant whose fruits have a high content of vegetable oil with a high calorific value, which is sown with the express purpose of using it for biofuel generation.

In the publication of Benavides et al., (2007), it was found that biofuel of higuerilla oil has excellent lowtemperature flow properties. Engine tests with conventional fig/diesel biodiesel blends, in the range of biodiesel ratios tested, show that as the proportion of biodiesel in the mix increases, the specific fuel consumption increases, while the effective performance and $\mathrm{CO}$ and $\mathrm{CO} 2$ emissions practically remain constant.

In the present study, 7457 Watts of power tests were carried out, with three types of biodiesel, in which fuel consumption also increased by increasing the proportion of biodiesel, that is, when generating B-20, except when it was tested with $100 \%$ biodiesel B100.

\section{Conclusion}

It was possible to generate biofuel known as biodiesel in 3 types, B-5 consisting of $95 \%$ diesel and 5\% castor oil; B20 made up of $80 \%$ diesel and $20 \%$ castor oil, and B-100 made up of $100 \%$ castor oil, from the mixture of methanol, potassium hydroxide and castor oil or higuerilla. The conditions that allow obtaining better biodiesel yields were obtained with a sample of $0.0001 \mathrm{~m}^{3}$ of type $\mathrm{B} 5$ at a temperature of $136^{\circ} \mathrm{C}$ and a consumption time of 0.07 hours.

Biodiesel represents an economic and environmental advantage over diesel, which is the fuel that is traditionally used in pumps for farm irrigation. The production of $0.001 \mathrm{~m}^{3}$ of B-5 has a cost of $\$ 0.11$ and B-100 has a cost of \$ 1.62. The biofuel should be stored by applying the corresponding safety standards so that it can be used efficiently and for a short time.

\section{Acknowledgments}

My sincere thanks to my fraternal friends and teachers, Dr. María Rodríguez Gámez, Ph.D. and Ab. Antonio Vázquez Pérez, Mgs., For the review and comments of this work. To Ing, Manuel Saltos Giler, for his valuable guidance in the development of this research.

\section{References}

Alexander, G. \& Boyle, G. (2014). Introducing renewable energy. Cambridge: Oxford University Press.

Benavides, A., Benjumea, P., \& Pashova, V. (2007). The biodiesel of fig oil as an alternative fuel for diesel engines. Dyna, 74 (153), 141-150.

Castro, M. (2011). Towards a diversified energy matrix in Ecuador. Quito: CEDA.

Cornejo, M. \& Estrada, O. (2012). Characterization of fig oil of two wild varieties for the production of biodiesel in the Mezquital Valley region, Hidalgo. Chihuahua-Mexico: Technological University of the Mezquital Valley.

Ermayanti, N. G. A. M., Oka, I. G. L., Mahardika, I. G., \& Suyadnya, I. P. (2016). Free testosterone level and quality of cauda epididymis sperm of local rabbit that given commercial feed supplemented by cod fish liver oil. International Research Journal of Engineering, IT \& Scientific Research, 2(3), 1-8.

Kammen, D. (2014). Taxonomy of renewable energy. Cleveland: Elsevier.

Paredes, J. R., Ramírez, C., \& John, J. (2017). Variable Renewable Energies and Their Contribution to Energy Security: Complementarity in Colombia.

Rodriguez, M. \& Vazquez, A. (2018). La enerrgía fotovoltaica en la provincia de Manabí. ISBN: 978-9942-948-205. Universidad Técnica de Manabí, Ediciones UTM-Unidad de Cooperación Universitaria. https://www.utm.edu.ec >index.php

Singh, D. (2016). Study of ethno-botanical flora of dakingari, kebbi state Nigeria, west tropical Africa. International Research Journal of Engineering, IT \& Scientific Research, 2(5), 17-28.

Vivas, F. E. V., Cuello, R. L. C., Macías, D. M., \& Rosado, G. P. (2017). Elaboration of essential oil from the oregano for medicinal use sheet. International Journal of Physical Sciences and Engineering, 1(1), 81-87. https://doi.org/10.21744/ijpse.v1i1.22

WEC (2010). Survey of energy resources. London: World Energy Council. 